\title{
The Feminine in the Poetry of Yunus Emre: A Case Study in the Hierophanic Dialectics of Mystical Islamic Experience
}

\author{
Vassilios Adrahtas
}

check for updates

Citation: Adrahtas, Vassilios. 2021. The Feminine in the Poetry of Yunus Emre: A Case Study in the Hierophanic Dialectics of Mystical Islamic Experience. Religions 12: 727. https://doi.org/10.3390/rel12090727

Academic Editors: Milad Milani, Zahra Taheri and Aydogan Kars

Received: 4 August 2021

Accepted: 1 September 2021

Published: 6 September 2021

Publisher's Note: MDPI stays neutral with regard to jurisdictional claims in published maps and institutional affiliations.

Copyright: (C) 2021 by the author. Licensee MDPI, Basel, Switzerland. This article is an open access article distributed under the terms and conditions of the Creative Commons Attribution (CC BY) license (https:// creativecommons.org/licenses/by/ $4.0 /)$.
Department of Humanities and Languages, The University of New South Wales, Sydney 2052, Australia; v.adrahtas@unsw.edu.au

\begin{abstract}
This article is about the most important Turkish Sufi poet and, more specifically, about the presence and the pragmatics of 'the Feminine' in his experience-inasmuch as the latter is reflected in his work. To be sure, this is a case study, in the sense that it aspires to provide only an idea as to how 'the Feminine' pervades Sufi hierophanics/religion, and also in the sense that it does not assume to be a comprehensive and exhaustive discussion-not even of Yunus Emre himself. Select(ed) poems of Yunus Emre are explored in the methodological light of what Mircea Eliade has dubbed 'hierophanic dialectics', and what Catherine Clément and Julia Kristeva regard as 'the Feminine' in relation to the sacred/religious from the perspective of social anthropology and psychoanalysis. In the poetry of Yunus Emre 'the Feminine' turns out to be the subtle yet decisive challenge, opposition, and subversion that, on the one hand, negates symbolic Islam and, on the other, affirms imaginary Islam in the name of the Islamic real-to evoke the terminology of Jacques Lacan.
\end{abstract}

Keywords: Yunus Emre; the Feminine; hierophanic dialectics; mystical experience; deconstruction; literary analysis; phenomenology of Sufi

\section{Introduction: Yunus Emre Contextualised}

Yunus Emre ${ }^{1}$ (c. 1240-c. 1320) is regarded as the greatest and most important Turkish Sufi poet; a poet that sanctified, so to speak, the vernacular Turkish language of his time-doing, in this respect, something similar to what his contemporary Dante Alighieri (c. 1265-1321) did for the spoken Italian language of his birthplace. Yunus Emre was a peasant whom life turned into a nomad. He lived under the Seljuk Sultanate of Rum or Iconium (1077-1308) and during his lifetime the socio-political environment was so volatile that no less than ten successive rulers assumed power. Moreover, he was born at the year of the so-called Baba Ishak revolt $(1240)^{2}$ and witnessed the violence and the devastation of the Mongol conquest. Contrary to another contemporary of his, namely, Jalaladdin Rumi (1207-1273), Yunus Emre never had anything to do with the circles of authority at the Iconium court, where the culture of the day was heavily influenced by Byzantium.

The fluidity, tension, and violence of his era were especially due to a number of changes that took place rapidly and abruptly. In particular, the activities of the ghazis that came from the East contributed to the nomadisation of much of subsistence and material culture, causing thus a shift from land cultivation to livestock and setting in motion successive waves of migration (Vryonis 1975). In this sense, the world of Yunus Emre was a world of dislocation, both physically and spiritually. It was especially the spiritual dislocation and uprooting that necessitated a quest for identity consolidation, which to a great extent was satisfied thanks to the rediscovery of tradition in Central Asian culture. The so-called babas were the ones that took the lead in this by introducing a revolutionary new spirit regarding 'roots'. In this connection, some of the most famous babas, who also seem to have had some kind of direct bearing on Yunus Emre, were Haji Bektash Veli (1209-1271), Taptuk Emre (c. 1210-?), Sari Seltik (?-1298), and Barak Baba (1257-1307). 
Along with the Babai movement came an appreciation of the matriarchic structure that characterised old peasant Turkish society - an element that one should definitely keep in mind when delving into 'the Feminine' in the poetry of Yunus Emre. Furthermore, the masses of Anatolia were exposed to ancestral shamanistic beliefs and practices that stressed God's fatherhood and compassion through such names as Tan $(g) r i$ and Chalap, respectively (Boyle 1972, pp. 177-93). All this, combined with the Shi'ite and Sufi background of the babas, as well as the official Sunni religious agenda, created a highly heterogeneous, yet inclusive and syncretic, state of affairs. Thus, it is not only reasonable, but even more so expected that from within the dialectics of the latter substantial challenge, opposition and subversion could be generated. In terms of a socio-political understanding of religion, the turmoil of the time was a real crisis and as such became the perfect context and occasion for the emergence of prime mystical experience and subsequent forms of institutionalised mysticism.

To put it otherwise, Yunus Emre was born and bred within a crisis and he took it upon himself to find a way out of the crisis. This is the whole point in the dramatic endeavour of his hierophanic quest, his radical experience and, finally, his unique poetry. Living at the margins, he made the mountain his existential space; through his escape into the Taurus Mountains he sought consolation, at first, and then encouragement: a leap of mystical love. This was the love into which Yunus Emre was initiated by the obscure yet formidable figure of his spiritual master, namely, Taptuk Emre. As far as the present study is concerned, in the case of Yunus Emre's erotic experience of Taptuk-in some respects, the equivalent of the relationship between Rumi and Shamz-the feminine and the masculine are just too obvious as the two sides of the same coin. However, the truly pressing question that one feels the need to pose is the following: who stands for 'the Feminine' and what exactly are the latter's qualities?

\section{Theoretical and Methodological Clarifications: Looking for the Hidden}

The perspective of 'hierophanic dialectics' in the present study follows more or less the meaning that the term has acquired in the work of Mircea Eliade (1949, pp. 1-50), that is, the co-existence of the profane-which he identifies with the physical and/or the social-and something that defies it within one and the same means of manifestation of the Sacred (i.e., a hierophany). Where I deviate from the great Romanian scholar is in relation to his cosmological orientation-since hierophanies can also refer to history -and in the sense that the dialectics I will be utilising in this study is one that features between the field of sameness (society) and the field of otherness (hierophanies), on the one hand, and between what undermines society (i.e., the profane) and what underlines society (i.e., religion) in the experienced presence/absence of what is regarded as the Sacred. It is this particular understanding that enables me to relate a prominent religionswissenschaftliche idea with the psychoanalytical insights of Jacques Lacan, which I will clarify at the end of this section.

To be sure, in a study that is in search of 'the Feminine' one should always keep in mind that the point is not, primarily and basically, to identify the elements that are about or come from women or even feminism-although these are significant in themselves as well — but to discover and bring to the fore the elements that have been silenced-especially in texts of the past-by the dominant religio-social order, which by nature or habit has been the main embodiment of 'the Masculine'. This rationale, in particular, has been pursued by two prominent women scholars, namely, Catherine Clément and Julia Kristeva, in their book Le féminin et le sacré (1998), within a framework that lies in the interstices of anthropology, studies in religion, and psychoanalysis. In what follows I critically present their perspective, upon which I will heavily draw, based on what I have written in a review of their work.

The topic of the book is ' ... the feminine. Not women-at least, not more than men-and of course not feminist ideology. What then? What is this feminine after all? ... to the extent that this book is about the feminine, equally so it is about the masculine. 
For how is it possible to speak about the former, if at the same time one does not speak about the latter? Hence, for the authors, if the masculine is the Father, the feminine is the Mother; if the masculine is the Law, the feminine is Nature; if the masculine is Power, the feminine is Tenderness; The Word over against the Body. However, the easier one utters the words "mother", "nature", "tenderness", and "body", the harder they can determine them via the structure of language, that is, via the masculine. Consequently, if [these words] are to belong truly to the domain of the feminine, they have to be linguistically indeterminate; they have to function in terms of memory. In this manner, though, they acquire a different access to the Sacred: they "remind" to us that there is always a lack, a fundamental deprivation in Being.

But what about the masculine? What happens with the relationship between the masculine and the Sacred? The authors ... allow us to articulate an answer on the basis of what they say about the phenomena that belong to the order of the Word of the Father. To appreciate, though, such an answer, one should take into consideration what Religionswissenschaft calls "hierophanic dialectics". This is about a synthesis between the constitution of the structures of culture and their rupture ... In other words, since the Sacred is totally absent, what we see in a hierophany is the aspect of the profane on the one hand, and the aspect of the rupture of the profane on the other. The profane is not the opposite of the Sacred, but the aspect which is necessary for the idea of [the] deprivation [of the Sacred] to be constituted. It is possible to speak about rupture, about something referring to a "ganz Andere", only if there exists a quasi-constituted structure, a Same. So the masculine is precisely this Same, whatever constitutes one within history and culture as a structure/subject. The masculine is the profane aspect of every hierophany, whereas the feminine retains for itself the role of the much disturbing, but also much required Other aspect. In this manner, "hierophanic dialectics" is a constant transition from the Other to the Same, and vice versa; a constant negotiation of what is profane and what is not.' (Adrahtas 2002, pp. 238-40).

This critical feminine perspective ties up thoroughly with 'hierophanic dialectics', although I will not be utilising the specific descriptions of the profane and the Sacred as Catherine Clément and Julia Kristeva present them. Nevertheless, I will be thoroughly utilising the consequences of their descriptions, namely, the fact that 'hierophanic dialectics' entails ruptures that are suggested by the use of indeterminate language-feminine language, for that matter-and bring forth the deprivation of Being. Of equal importance is not only the constant re-negotiation of what is profane, but even more so the consistent challenge of the limits of religion. To put it in terms directly applicable to the present study, 'the Feminine' in the poetry of Yunus Emre lies in everything that disrupts the authority of religion, not so much to the detriment of religion, as to its transformative re-affirmation. In the poetic language of Yunus Emre anything that subverts common or institutional-in both cases, patriarchal and masculine-forms of Islam, even if they are part of tasawwuf, represents the only genuine embodiment of 'the Feminine', that is, the mystical experience of Allah.

In turn, Jacques Lacan's famous triptych 'imaginary (imaginaire)—symbolic (symbolique)—real (réel)' (Lacan and Granoff 1956, pp. 265-76) is applied in the present study in a quite specific way, that is, without the negative connotations that accompany these terms. The latter are rather used in a positive heuristic sense, in order to bring forth the supressed or implicit dialectics, negotiation, and interplay between 'the Masculine' and 'the Feminine'. In particular, since in the case of Yunus Emre there is a triptych involved in the 'hierophanic dialectics' that his poetic message exemplifies, Lacan's own triptych seems quite pertinent methodologically to distinguish between the images associated with the experience of Yunus Emre (imaginary Islam), the signifiers the latter uses or opposes (symbolic Islam), and the 'reality' that exceeds and lies beyond both his experience and signifiers (the Islamic real). Moreover, 'the Feminine' in his poetry is not something straightforward, but rather an incessant interaction between what Islamic mysticism is and what it can or should be. 
In other words, in the poetry of Yunus Emre mysticism can, but need not be, identified with 'the Feminine', whereas prime mystical experience and 'the Feminine' are equivalent.

\section{Deconstructing 'the Masculine', Encountering 'the Feminine'}

Your love has wrested me away from me, You're the one I need, you're the one I crave. Day and night I burn, gripped by agony, You're the one I need, you're the one I crave.

I find no great joy being alive, If I cease to exist, I would not grieve, The only solace I have is your love, You're the one I need, you're the one I crave.

Lovers yearn for you, but your love slays them, It has God's images-it displays them, You're the one I need, you're the one I crave.

Even if, at the end they make me die. And scatter my ashes up to the sky, My pit would break into this outcry: You're the one I need, you're the one I crave.

Let me drink the wine of love sip by sip, Like Mecnun, live in the hills in hardship, Day and night, care for you holds me in its grip, You're the one I need, you're the one I crave.

'Yunus Emre' is my name, Each passing day fans and rouses my flame, What I desire in both worlds is the same: You're the one I need, you're the one I crave. (Smith 1993, p. 124)

If it is easy to say that Yunus Emre identifies with the ' $I$ ', who is the 'You' he repeatedly refers to in the poem? 'You're the one I need, you're the one I crave' (Bana seni gerek seni)! Is it Allah or is it Taptuk Emre? Or could it be both as one? In either case, the language used is so much loaded with erotic emotionality ${ }^{4}$ that one cannot escape posing the question of 'the Feminine' in relation to Yunus Emre's experience of the Sacred, on the one hand, and the understanding of himself within this experience, on the other. But let us take this poem line by line. First of all, let us start from the force-even if it should be taken as a mild one, as 'aldı benden' entails— that is implied at the very beginning: 'Your love has wrested me away from me' (Aşkın aldı benden beni) (my emphasis). Love is mentioned as a force, something powerful and thus, one could say, rather masculine. Then the natural connotation or implication would be to imagine a masculine force-divine love, for that matter, as a whole field of religious signification-being exercised upon a female. In this respect, divine love is the condition of possibility for the experience of 'the Feminine' to emerge- as a rupture in the signification of religious language and as a profanity in the dialectics of hierophanic experience. In any case, the power of divine love that wrests brings Yunus Emre forward as the agent of 'the Feminine', regardless of who exactly is 'the Masculine', Allah or Taptuk Emre in lieu of Allah.

'Need' and 'crave' (gerek) are two verbs that do not seem—at first, at least- to lend themselves especially to 'the Feminine', but then why should the semantics of power we just saw be intertwined with the semantics of helplessness and dependency? Yunus Emre uses words that affirm power and at the same time subvert it. His poem might make perfect sense grammatically, but experientially it proves to be so self-contradictory that it explodes under the sheer pressure of its linguistic meaningfulness. The point is not that philosophically one could see here a balance of oppositional forces (powerhelplessness), but the very fact that there is power on the one hand, plain and simple, and 
there is helplessness on the other, plain and simple. In other words, balance is only the rationalisation attempted in light of the disturbing possibility of unbalance. This is exactly what the balancing power of 'the Masculine' is really afraid of! (cf. Monick 1991).

'I burn, gripped by agony' (Ben yanarım) (my emphasis). Divine love not only behaves like a power that wrests, but also like a force that burns and grips. The image herein is one of suffering and pain, which in themselves once again point beyond 'the Masculine' through 'the Masculine'. The latter comes up as a valid consideration, although the poem does not mention it, because at a more fundamental level the image under discussion is about violence. However, this means that it is thanks to the force of 'the Masculine' that the emotionality of 'the Feminine' emerges in the experience of Yunus Emre, as if the one cannot be without the other. This is true insofar as there is a further existential registerhowever elusive it may appear in the original Turkish-namely, agony, insinuating that something has been suppressed and silenced, but not totally or once and for all. Agony is, in a sense, the sinister face of divine love; a face that bespeaks of a tension within one and the same experience. On the one hand, there is the content, so to speak, of the experience and, on the other, what the experience lacks. Moreover, the mystical experience of Yunus Emre is not fueled so much by its content, which seems to be informed by the violence of 'the Masculine', as it is by what it lacks and desperately needs, which is what 'the Feminine' stands for...

Suddenly the tense atmosphere of the poem turns into tenderness: 'The only solace I have is your love' (Aşkın ile avunurum) (my emphasis). Divine love is not portrayed anymore as a violent masculine force, but as a comforting female presence. At this point 'the Feminine' is quite pronounced and in stark opposition to everything that has been implied thus far. One is almost tempted to think that this opposition is an additional linguistic feature that (re)orientates the attention of the audience to a true challenge against 'the Masculine' in the poem and the experience the latter reflects. In other words, it is only natural to dub such a challenge 'the Feminine', especially when the 'solace' (avuntu) mentioned in the line examined is suggested as ' $[\mathrm{t}$ ] he only' one; whereas 'the Masculine' could be a 'solace' of some kind, it could not be the only, that is, the real one. All this rationale becomes even more likely, since what follows in the poem reiterates the masculine contour of the poem: the violence that the divine love exercises upon her lovers knows no limits—it simply 'slays' (öldürür) them!

Divine love 'has God's images - it displays them' (my emphasis), which means that it is not identified with Allah, although Allah is relatable through that love. Again, what the Muslim regard as their Sacred is not relatable directly through this love, but through the images of Allah that it bears (witness to). To be more precise, divine love 'displays' the images of Allah literally, 'fills with manifestation' or 'is fully transformed' (Tecellî ile doldurur) - just like a woman might display, manifest her beauty and become fully transformed in the process. The connotations of 'the Feminine' cannot be missed here, but the real issue lies in the mediation of Allah. More specifically, who embodies divine love? Is it the authority of 'the Masculine' Islamic that prescribes what this love is and what it is not, or is it the elusiveness of 'the Feminine' Islamic that creates a space of communication? In more specific terms, does Yunus Emre have in mind an orthodox religious channel through which divine love is expressed, or does he find it embodied via an unorthodox manner in the person of Taptuk Emre? I think that the whole poem is much more inclined towards the second option, which means that it functions as a kind of allegory.

In the second last stanza of the poem, the mentioning of Mecnun (Majnun), whose story of course makes no sense without Leyla (Layla), places quite explicitly 'the Feminine' right at the core of the poem. The crazy lover of Leyla becomes the archetype of what Yunus Emre feels and goes through; of what he wants to be(come) in his relation with the beloved Sacred. To phrase it in the terms of the image that is invoked, what Yunus Emre regards as the Sacred arouses him through a power-this time not violent, but no less strong-that resembles that of 'the Feminine'. It is as if only the erotic experience of the male towards the female can encapsulate and depict the love the mystic feels towards God. Nevertheless, 
the violence of 'the Masculine' is not obliterated; on the contrary, it remains quite visible and felt, for the mystic is called to 'live in the hills in hardship' (my emphasis), being still in the 'grip' of an ambivalent 'care'-both denoted in the original Turkey by 'endîşem'. The latter is associated, to be sure, with his craving, but it also pertains to something that keeps him constantly in a state of alert. Once again, the language employed in the poem signifies the tangible experience (of 'the Masculine'), but also the intangible condition (of 'the Feminine') that make the experience possible. ${ }^{5}$

In the same stanza Yunus Emre implores, 'Let me drink the wine of love sip by sip' (Aşkın şarâbından içem) (my emphasis). The image of wine brings automatically to mind intoxication, and the latter recalls directly the notion of ecstasy (see Smith 2013), which stands opposed to the spirit of order and rationality, typical metonymies of 'the Masculine'. In this respect the poem presents 'the Feminine', through the metonymy of 'wine', as the condition of experiencing divine love. Yet, once again, the hint is not bereft of ambivalence: as implied in the original Turkish, the wine of divine love will be consumed 'sip by sip', which means slowly and most likely - that is the insinuation-tantalizingly, since the mystic lover (aşikik) cannot take it all in at once, even though they desperately want to. Because of their partial status within 'the Masculine' symbolic of religion, that is, the legalistic implementation of sharia and the ritualistic pursue of tasawwuf, the wine of love is simply too much for them, and so its consumption requires caution. The same ambivalence reverberates at the very end of the poem, where Yunus Emre says, '[e]ach passing day fans and rouses my flame' (literally, 'my wood', presumably burning up, in the original Turkish; my emphasis), since the image of the flame can be thought of both as a destructive and a creative element. It seems that the love of Allah (re)creates the lover the very moment it destroys them! This is the most succinct way to conceptualize Yunus Emre's experience of fana wa baqa.

In the poem titled 'A Single Word Can Brighten the Face', two are the features that point to 'the Feminine': the image of ripening and the state of silence itself. The poem is about 'the value of words', which one way or another reflect and belong to the order of the symbolic within religion, that is, to 'the Masculine', but the value discussed is something that transcends this order and refers to the deep identifications in the existence of the mystic. This is where the imaginary comes into the picture and where the poem starts erupting. 'Ripened in silence, a single word/acquires a great energy for work.' Here the ripening (olgunlaşmak) of the word is portrayed as the slow and gradual process of human development within the womb. Thus, there is no word, no name, no order of the Father whatsoever, without the formless, without labour, without creation through the Mother. Even more, Yunus Emre prioritizes the latter, since it is only via this aspect of 'the Feminine' that the masculine words are to acquire their efficacy at the end; their efficacy, but not their value. Their value has always been there in the beginning, in 'the Feminine' hierophanic experience of the mystic. Thus, in light of this prioritization, the poem exhorts, 'Let a word mature inside yourself./Withhold the unripened thought.' It is this withholding that bespeaks of the importance of silence that hovers, so to speak, over the whole poem. In other words, Silence (sessizlik) becomes the negative of the Word; both are necessary for the emergence of the hierophanic order and, for that matter, its mesmerizing power: 'Yunus, say one last thing/about the power of words./Only the word "I" /divides me from God.'

'Ask Those Who Know' is one of those poems that at a surface reading seem to be totally irrelevant regarding 'the Feminine'; especially for those who think that the latter lies in discovering simply references to women, the female, or feminist sensitivities. Not that these are not significant, but they are totally misleading if they are regarded as the most important or the all-inclusive topos of 'the Feminine'. My approach is quite different. It starts prompted by the questions: 'Who is the Khan on the throne? ... What are all of Solomon's riches?' Then, it ends delving into further questions: 'What are You? What am I?' Questioning amounts to challenging, and in the context of the discourse of Yunus Emre challenging can only be directed to the religious structure of Islam. Besides the poem itself, it is evident that the mystic is challenging not only the validity, but also the very 
existence of the wordly/historical realization of Islam: 'Ask Yunus and Taptuk/What the world means to them./The world won't last.' This is a direct reference to the possibility and, for that matter, to the necessity—-here and now, in the future, anytime - of subverting (the dominant and masculine) meaning. It is precisely this possibility/necessity that the hierophanic prerequisite and aftermath of religion owes to 'the Feminine', the quintessence of the Sufi experience that Yunus Emre inherited, perpetuated and, most of all, transformed.

\subsection{Am Before, I Am After}

I am before, I am after.

The soul for all souls all the way.

I'm the one with a helping hand.

Ready for those gone wild, astray.

I made the ground flat where it lies,

On it I had those mountains rise,

I designed the vault of the skies,

For I hold all things in my sway.

To countless lovers I have been.

A guide for faith and religion.

I am sacrilege in men's hearts.

Also the true faith and Islam's way.

I make men love peace and unite;

Putting down the black words on white,

I wrote the four holy books right.

I'm the Koran for those who pray.

It's not Yunus who says all this:

It speaks its own realities:

To doubt this would be blasphemous:

'I am before, I am after', I say.

In the first stanza of this poem the hierophanic prerequisite and aftermath mentioned above is rephrased through a well-known theological trope: 'I am before, I am after', that is, I am the before and the after of religious experience; or I am the one who always was and always will be! However, I think that the focus of the stanza lies elsewhere; not in this quite obvious denotation, but in a rather elusive connotation. In particular, Yunus Emre seems to be referring to the element of compassion ( $\mathrm{rahma}$ - - so cardinal in Islam. Yet the mentioning of compassion is done in such an emphatic way that it moves beyond the conventional understanding of being lovingly accepting. Here it is about ' $[\mathrm{t}]$ he soul' that is there, present 'for all souls' and, for that matter, 'all the way' (my emphasis). But what is this 'soul for all souls' (canlara can), this 'soul' that can support and sustain 'all souls'? It seems to be something prior, through and beyond religion itself; something without which religion would not have been possible in the first place. The connotations of compassion go on-'I'm the one with a helping hand./Ready for those gone wild, astray' (my emphasis). Now the female contours of the poem become even more explicit, leading to the somewhat unforced conclusion that one is indeed encountering 'the Feminine' in the poetry of Yunus Emre. Nevertheless, not everyone can claim the 'helping hand' of this 'Feminine' compassion in their lives; only those who have 'gone wild, astray' of the prescriptions of religious law for the sake of religious truth.

The second stanza is rather cryptic as to why one should associate it with 'the Feminine', but once the text is left aside for a while in favour of its possible intertextualitywritten or oral-then the invisible starts becoming visible. To be more specific, I think that the image of compassion in the first stanza gives its place to the image of Sophia/Wisdom, operative in the world and the universe at large. 'I made the ground flat where it lies,/On it I had those mountains rise,/I designed the vault of the skies,/For I hold all things in 
my sway.' It is hard not to read in these lines the echo of certain texts that come from the wisdom literature of Judaism and Christianity, where the Sophia of God is the prime means of creation (cf. Proverbs 8: 27-29). Likewise, it seems that in Islam Allah is the creator but there is a 'Feminine' involved; not that the creative act of Allah is disputed or challenged, but what is indeed disputed or challenged is the exclusively 'Masculine' character of Allah's creativity. In light of this, the supportive and sustaining qualities revealed in the hierophanic experience of the mystic are corroborated further by a fundamental creative attribute with regards to what is regarded as the Sacred.

The third stanza of 'I Am Before, I am After' is one of those cases where we witness Yunus Emre's tour de force of 'hierophanic dialectics' - and it rarely gets better than that. 'I am sacrilege in men's hearts/Also the true faith and Islam's way' (my emphasis). How can it be both? How can it remain one and the same? It seems that everything depends on the faithful, on how they perceive, react, appreciate, and understand. What is regarded as the Sacred can trigger a vast number of responses, of course, but ultimately they all come under the mode of either underlining or undermining the conventions that make human life-forms possible. So it is this ambivalence in the specific two lines of the stanza that turn one's attention to religion ('Islam's way'), on the one hand, and to the profane ('sacrilege'), on the other. If the former can be validly called 'the Masculine' —and for more than one reasons in history and society it can-then the latter deserves to be called 'the Feminine'. Not only does it deserve the appellation, but it also deserves the consideration of the serious seeker, for it constitutes the more often than not neglected aspect of religious experience, the aspect that makes religion truly religion in the first place, namely, the presence of what is regarded as the Sacred within the latter's hierophanic manifestations.

At last the poet becomes clear, that he is talking about something that goes beyond 'the Masculine'. Indeed the fourth stanza-indirectly, but undeniably-claims that this something-beyond-'the Masculine' is not men's business: 'I make men' (my emphasis) do this or that, regardless of the latter being religious or not. In a way, whatever men have been doing in history is not due to some kind of intrinsic male quality or power; fundamentally - and on the contrary, one might say - it has been the prerogative of something else. Furthermore, what is of special interest is what men are involved in doing: 'love', 'peace', unity, creativity. However, these are not the usual male things of violence, war, clash, and destruction. Understandably, one could say, for humanity has its female side as well. Thus the poem is having men realizing what women should be presented as doing. This, if anything, is a prime example of 'the Feminine' ambiguity that permeates the poetry of Yunus Emre. The 'black words' is one thing and the 'white' upon which they are written is quite another. Both are needed, however, and the one is there because of the other. The dialectical disposition of the poet goes on and on, ending in a triumphant, so to speak, declaration that brings us back to the theme of Allah's mediation; a mediation that in itself thrives in ambiguity, strengthening once again the allusions of the poem with regards to 'the Feminine'. 'I wrote the four holy books right/I' $m$ the Koran for those who pray' (my emphasis); not Allah but ' $\mathrm{I}$ ', doing the work of Allah; the real work and not the conventional doings of religion.

The last stanza in the poem under discussion might be about a very peculiar possibility as far as the poet's intention is concerned. More specifically, the poet might be alluding to a certain type of absence within history. 'It's not Yunus' (my emphasis), the poem emphatically declares in the negative. 'It speaks its own realities' (my emphasis), the poem asserts, thus implying that the actual 'realities' of history represent a negativity; and this is precisely what the poem affirms in what follows. 'To doubt this would be blasphemous' (my emphasis). Yet, that is exactly what has been done; has it not been doubted time and again? To be honest, this doubt is the only certain thing, which means that religion itself systematically constitutes an act of negativity. However, the main question is: a negativity over against what? Here is where 'the Feminine', even as a hypothesis, has to come in. 'I am before, I am after' (evvel âhır heman benem) (my emphasis), not in-between. The latter 
is the topology of institutionalised religion run by the force of 'the Masculine', whereas the 'before' and the 'after' remain the utopia of 'the Feminine' ...

\subsection{Knowledge Should Mean a Full Grasp of Knowledge}

Knowledge should mean a full grasp of knowledge:

Knowledge means to know yourself, heart and soul.

If you have failed to understand yourself,

Then all of your reading has missed its call.

What is the purpose of reading those books?

So that Man can know the All-Powerful.

If you have read, but failed to understand,

Then your efforts are just a barren toil.

Don't boast of reading, mastering science.

Or of all your prayers and obeisance.

If you don't identify Man as God,

All your learning is of no use at all.

The true meaning of the four holy books.

Is found in the alphabet's first letter.

You talk about that first letter, preacher;

What is the meaning of that-could you tell?

Yunus Emre says to you, Pharisee,

Make the holy pilgrimage if need be.

A hundred times-but if you ask me,

A visit to the heart is best of all.

To be sure, religion offers knowledge: knowledge of what is regarded as the Sacred. However, is that knowledge enough? Is it 'a full grasp of knowledge'? Is that knowledge what the religious seeker has been after in the first place and all along? Yunus Emre is not implying anything anymore; he is rather crystal-clear as to the insufficiency of religious beliefs and practices in themselves. They have failed or, better, insofar as they have failed to enable a person to achieve self-knowledge, they have missed both their objective and the need to stay tuned in with their hierophanic origins and source. What is especially interesting for the purposes of the present study is how Yunus Emre phrases this failure and missing of the point as far as religion is concerned: 'your efforts are just a barren toil' (yere) (my emphasis), he deplores. The image of the barren ground, with its unmistakable connotations of infertility, brings to mind the traditional and/or premodern female who fails to fulfill their first and utmost purpose in life. Because what was a barren female in premodern societies? Virtually a mistake, an anomaly, a nobody. Religion risks becoming just like that, when it does not draw upon and adhere to the surplus that makes it possible in the first place. Once again the discourse of Yunus Emre works through the male and the female-and their tropes-in order to signify the presence/absence of 'the Feminine'.

'If you don't identify Man as God / All your learning is of no use at all.' To read this as an example of pantheism would be a total misreading; to read it as a kind of anthropology à la Feuerbach would be just wishful thinking. These two lines can only be read as a rupture that breaks up the poem from the inside, in order to signify that which is not within the signification field of the text itself. To put it in other terms, if the identification of Man and God makes any sense at all, it is because what is regarded as the Sacred can be something more than male-it can be female as well! This simultaneous bipolarity, that is, the affirmation and the negation of the symbolic signification within the 'champs religieux' (Bourdieu 1971), hints at an imaginary identification of the poet in the context of his mystical experience; an identification with the silenced and concealed 'Feminine' that substantiates yet again the transcendentality of the reality of the Islamic Sacred. 
Throughout the poem Yunus Emre is criticizing the Muslim scholar or 'preacher' as an authoritative representative of religious law, ritual, and morality. He, moreover, characterizes this representative as a 'Pharisee', echoing in this the famous 'woes' of Jesus against the scribes and Pharisees (Matthew 23). This is evidently a case of criticism of the masculine representatives of secondary and derivative religion over against the primary and original religiosity involved in 'hierophanic dialectics'. To the extent that this criticism is dialectical, one can justifiably postulate that the poet is implying this primary and original religiosity all along, and by extension that this religiosity is closer to 'the Feminine' than to 'the Masculine' associated with the power and authority of institutional religion. Practically speaking, this entails and presupposes a refocusing of religious attention, so that the intentionality of the faithful is internalised, on the one hand, and transposed to something more profound, on the other. It is this more profound level that one can call 'the Feminine', for it does irrupt into the mystical experience-seemingly from nowhere, but in effect from the unknown order of the real that is regarded as the Sacred-providing the mystic with qualities that are definitely not what the masculine social order would normally bestow.

'A visit to the heart is best of all'! The mystical experience of Yunus Emre breaks through —and at the same time breaks down-all the conventional requirements of religion, the 'Pillars of Islam' as they are known. The latter are not invalid, but they are not enough. This lack or insufficiency is what brings in the centrality of the heart. Not the mind, reason, or consciousness, but the heart, feeling, and affection are called upon when religion faces the problem of reinvigoration, renewal, and restoration to its prime appeal and impetus. To recall the connotations of the womb, birth, and motherhood I have already referred to, it seems that the heart could be thought of as a metonymy of the innermost place where a new creation can be materialised. In this sense, the heart is the mother, the womb and the cradle of religion; 'the Feminine' Other of 'the Masculine' Same, so much determining and at once too indeterminate in itself to be defined in a definitive way.

\section{Truth-Heart-Love-Body-Humility: The 'Feminine' Contours of Mystical Experience in Yunus Emre}

One could continue exploring the terra incognita of 'the Feminine' in the poetry of Yunus Emre by visiting and delving into numerous other cases of textual allusion. 'We were dry, but we moistened ... we married one another and flew ... in whatever hearts, in all humanity,/We planted the meanings Taptuk taught us', writes Yunus Emre in another poem, giving to 'the Feminine' some kind of flesh and bones through the images of fertilization and marrying. On another occasion the poet would sing in a tone of deep-felt gratitude: 'We became servants at Taptuk's door./Poor Yunus, raw and tasteless,/ finally got cooked, glory be to God.' Here Taptuk is portrayed as a motherly figure in a quite unique manner: preparing people for God just like a housewife prepares the daily food for her children! And of course one could go on talking about the importance of tears-hardly a manly expression of emotionality-in mystical life, as we can see in 'The Lover Is Outcast and Idle', or the image of the so feminine rose in the poem 'To Be in Love'.

In order to be as comprehensive as possible, I should mention that Yunus Emre alludes to 'the Feminine' in quite diverse modes and through a wide range of tropes. For instance in the 'If You Are In Love with Love' one comes across the worthlessness of the world, which can easily be translated into the worthlessness of the male and everything that may be implied by this. In 'Those Who Became Complete', the poet reveals the secret of mystical realization: 'Until we transform our Names, /we haven't found the Way'. But such a transformation would virtually amount to the transformation of the given masculine order, either religious or social. In whatever way one looks at it, the radical hierophanic critique of Islam on the part of Yunus Emre becomes a window through which one gets a glimpse of 'the Feminine'. Sometimes the glimpse is quite telling for the poetic language is almost saturated in allusions as is the case with the poem 'To Be Alone with You'.

In concluding this article I would like to sum up what I would dub the mystical experience of Yunus Emre and bring forth the contours of 'the Feminine' that sustain it. In 
particular, his experience recognizes Truth $(H a q q)$ as first and foremost. In a poem titled 'How Will You Find Haqq?' the poet exclaims: 'Put everything on fire! Burn up, so you can stand up!' Along with the all-pervasive and omnipresent Truth, so cherished in the various Sufi traditions, comes a radical socio-political critique. When the Truth of what is regarded as Sacred is present, the field of the Same reacts by calling it profane, whereas when it is absent the Same takes on Truth's prerogatives by proclaiming itself religion. In other words, Yunus Emre is invoking the present of the Sacred and its Truth so that-even momentarily - everything gets suspended and re-started. Only then the new order of things through the mystic's intervention can have-for a limited time, of course- the aura of authority. But why should this 'hierophanic dialectics' be intrinsically associated with 'the Feminine'?

The answer to this question lies-once again-in the fact that the dialectics of the Sacred emerge as-and result in—attributes anything but masculine. In 'The Mature Ones Are a Sea', the place of Truth is to be found in the affection, the feelings, and the emotionality of the heart; not in the discipline, the order and the austerity of reason. To recall the poet's own words: 'The arrow of Love has pierced my heart', and 'My heart is the throne of the Beloved/the Beloved the heart's destiny:/Whoever breaks another's heart will find no homecoming/in this world or any other'. That is how central the heart is. Nevertheless, 'the Feminine' contours of mystical experience become even more feminine, when the poet declares that he has 'Encountered the House of Realization' in the sheer corporeality of the human being - his own and that of others. In reality, his words reveal a cryptic corporeality of faith, in which the religious experience is realised through the reverence of the human body. Before the body Yunus Emre is compelled to bow and to 'Be a Lover'; a lover whose love transforms into the forbearance and humility of the Feminine-and turns the world upside down for ever.

\section{True Speech Is the Fruit of Not Speaking}

True speech is the fruit of not speaking.

Too much talking clouds the heart.

If you want to clear the heart,

Say this much, the essence of all talking:

Speak truly. God speaks through words truly spoken.

Falsity ends in pain.

Unless you witness all of creation in a single glance,

You're in sin even with all your religion.

The explanation of the Law is this:.

The Law is a ship. Truth is her ocean.

No matter how strong the wood,

The sea can smash the ship.

The secret is this:

A 'saint' of religion may in reality be an unbeliever.

We will master this science and read this book of love.

God instructs. Love is His school.

Since the glance of the saints fell on poor Yunus.

Nothing has been a misfortune.

Funding: This research received no external funding.

Data Availability Statement: Not applicable.

Conflicts of Interest: The author declares no conflict of interest.

\section{Notes}

In what follows in this Section I mainly draw on (Athanassiadi 1996, pp. 11-30; Cahen 2001; Vryonis 1971).

See (Ocak 2015). 
3 All references to the poetry of Yunus Emre are taken from 'A Collection of Poems by Yunus Emre, Turkish Sufi Poet (AD.1240-1320)' (available online: http:/ / traditionalhikma.com/wp-content/uploads/2015/03/Collection_of_Poems_A_-_Yusus_Emre.pdf) (accessed on 6 January 2021).

4 For this kind of emotionality in Sufism, see (Lewisohn 2014, pp. 150-80).

5 For a full-blown case of 'hierophanic dialectics' with regards to the couple Leyla and Mecnun and its implication for 'the Feminine', the poem 'I Am A Fatherless Pearl' (my emphasis) is quite indicative.I am a fatherless pearl unrecognized by the sea.I am the drop that contains the ocean.Its waves are amazing. It's beautiful to be a seahidden within an infinite drop.When Majnun spoke Layla's name,he broke the meter of his poem.I was both Layla and Majnun who adored her.Mansur did not speak idly of Unity.He was not kidding when he said, "I am Truth."In this world of many,You are Joseph and I am Jacob.In the universe of Unity,there is neither Joseph nor Canaan.That my name is Yunusis a problem in this material world.But if you ask my real name,it is the Power behind all powers.

\section{References}

Adrahtas, Vassilis. 2002. Catherine Clément \& Julia Kristeva. Le féminin et le Sacré. Threskeiologia-Hiera/Vevila 3: 238-40. (In Greek) Athanassiadi, Polymnia. 1996. Yunus Emre. Athens: Apameia. (In Greek)

Bourdieu, Pierre. 1971. Genèse et structure du champ religieux. Revue Française de Sociologie 12- 13: 295-334. [CrossRef]

Boyle, John Andrew. 1972. Turkish and Mongol Shamanism in the Middle Ages. Folklore 83: 177-93. [CrossRef]

Cahen, Claude. 2001. The Formation of Turkey: The Seljukid Sultanate of Rum, Eleventh to Fourteenth Century. London: Routledge.

Eliade, Mircea. 1949. Traité D'histoire des Religions. Paris: Payot.

Lacan, Jacques, and Wladimir Granoff. 1956. Fetishism: The Symbolic, the Imaginary and the Real. In Perversions. Edited by Lorand Sandor. New York: Gramercy, pp. 265-76.

Lewisohn, Leonard. 2014. Sufism's Religion of Love, from Rābi'a to Ibn 'Arabī. In The Cambridge Companion to Sufism. Edited by Ridgeon Lloyd. Cambridge: Cambridge University Press.

Monick, Eugene. 1991. Castration and Male Rage: The Phallic Wound. Toronto: Inner City Books.

Ocak, Ahmet Yaşar. 2015. Babai. In Encyclopaedia of Islam, THREE. Edited by Kate Fleet, Gudrun Krämer, Denis Matringe, John Nawas and Everett Rowson. Leiden: Brill Publisher.

Smith, Grace Martin. 1993. The Poetry of Yünus Emre, A Turkish Sufi Poet. Berkeley and Los Angeles: University of California Press.

Smith, Paul. 2013. Wine of Love: An Anthology Wine in the Poetry of Arabia, Persia, Turkey \& the Indian Sub-Continent from Pre-Islamic Times to the Present. Victoria: New Humanity Books.

Vryonis, Speros. 1971. The Decline of Medieval Hellenism in Asia Minor and the Process of Islamization from the Eleventh through the Fifteenth Century. Berkeley: University of California Press.

Vryonis, Speros. 1975. Nomadization and Islamization in Asia Minor. Dumbarton Oaks Papers 29: 41-71. [CrossRef] 